
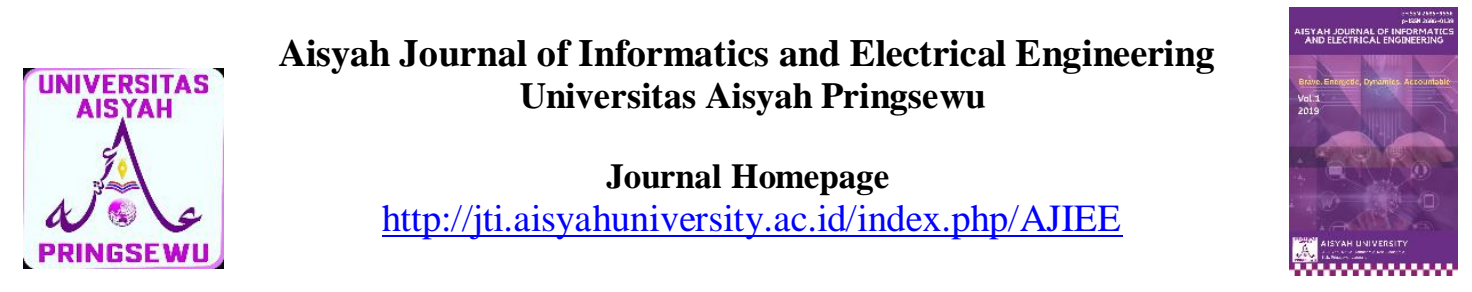

\title{
PERANCANGAN APLIKASI PENJUALAN TAPIS LAMPUNG BERBASIS ANDROID MENGGUNAKAN ALGORITMA STRING MATCHING
}

\author{
Hafsah Mukaromah ${ }^{1}$, Kiki Rizki Amelia ${ }^{2}$ \\ Teknik Informatika, Fakultas Teknologi dan Informatika Universitas Aisyah Pringsewu \\ Jl. A. Yani, No 1A, Tambahrejo, Kec. Gadingrejo, Kab. Pringsewu Lampung e-mail: hafsahkama@gmail.com
}

\begin{abstract}
Abstrak
Berbagai masalah yang dialami pelanggan pada saat akan melakukan pembelian tapis seperti, tidak mengetahui tapis apa yang dicari, keterbatasan informasi mengenai produk tapis yang dicari dan jumlah persediaan produk. Hal ini disebabkan belum tersedianya katalog elektronik berbasis mobile yang dapat membantu dan mempermudah pelanggan dalam mencari informasi mengenai produk tapis.

Maraknya pengguna smartphone android di kalangan masyarakat dengan berbagai kelebihannya seharusnya permasalahan di atas tidak harus terjadi lagi. Penelitian ini bertujuan untuk menyediakan layanan yang dapat membantu dan mempermudah pelanggan dalam mencari dan melakukan pembelian produk tapis online melalui smartphone android. Pada aplikasi ini menerapkan algoritma pencocokan string Brute Force pada search box sebagai algoritma dalam aplikasi pencarian produk tapis. Hasil pencarian yang ditampilkan berupa detail produk tapis beserta lama waktu pencarian. Metode yang digunakan dalam pengembangan aplikasi ini adalah metode prototype dan menggunakan UML (Unified Modeling Language) sebagai alat bantu pemodelan sistem. Hasil dari penelitian pada toko Ninda Tapis Lampung dapat disimpulkan bahwa dengan adanya aplikasi penjualan tapis online dapat mempermudah pelanggan dalam mencari informasi produk dan melakukan pemesanan produk tapis secara online.
\end{abstract}

Kata Kunci : tapis, penjualan online, pencocokan string, brute force, prototype, UML

Aisyah Journal of Informatics and Electrical Engineering 


\section{PENDAhuluan}

A. Latar Belakang

Tapis Lampung merupakan kain tradisional yang berasal dari Provinsi Lampung. Kain Tapis saat ini diproduksi oleh pengrajin dengan ragam hias yang bermacam-macam sebagai barang komoditi yang memiliki nilai ekonomis yang cukup tinggi. Salah satu toko yang menjual kain tapis di wilayah kota Bandar Lampung yaitu Ninda Tapis Lampung. Ninda Tapis Lampung adalah toko tapis yang menjual aneka ragam produk kerajinan tenun tapis, seperti tapis sarung, sulam usus dan hiasan dinding tapis. Namun, pada proses bisnisnya toko Ninda Tapis Lampung masih memiliki beberapa permasalahan yang sering dialami oleh pihak konsumen. Diantaranya, ketika seseorang akan berbelanja tapis mulai dari tidak mengetahui tapis apa yang mereka inginkan karena tidak adanya suatu bentuk katalog elektronik, keterbatasan informasi mengenai produk tapis yang dicari dan jumlah persediaan produk. Hal ini mengakibatkan produk yang diinginkan konsumen tidak sesuai dengan persediaan yang ada. Selain itu, pemesanan produk yang masih menggunakan sistem manual. Dimana setiap konsumen yang ingin membeli produk tapis harus datang ke toko.

Berdasarkan permasalahan di atas dan semakin berkembangnya teknologi secara pesat, maka diperlukan suatu media yang dapat mempermudah konsumen untuk melihat produk toko Ninda Tapis Lampung, mendapatkan info barang terbaru dan melakukan pemesanan produk tanpa harus datang ke toko. Dalam hal ini penulis ingin mencoba membuat sebuah perancangan aplikasi penjualan tapis berbasis android yang nantinya dapat memberikan informasi kepada masyarakat khususnya konsumen/pelanggan toko Ninda Tapis Lampung tentang informasi produk tapis yang dijual melalui sebuah aplikasi mobile berbasis android. Serta memberikan kemudahan kepada konsumen/pelanggan untuk memesan produk tapis secara online. Mengingat hampir semua kalangan masyarakat sudah menggunakan smartphone yang berbasis android. Dalam pembuatan sistem penjualan online produk tapis toko Ninda Tapis Lampung menggunakan algoritma string matching atau pencocokan string. Algoritma string matching yang digunakan adalah algoritma brute force.

\section{B. Rumusan Masalah}

Berdasarkan latar belakang tersebut perumusan masalah dari penelitian ini adalah:

1. Bagaimana merancang dan membangun aplikasi penjualan online berbasis android dengan memanfaatkan teknologi informasi?

2. Bagaimana mengimplementasikan algoritma string matching untuk pencarian nama produk tapis pada toko Ninda Tapis Lampung?

\section{Batasan Masalah}

Penelitian ini memiliki batasan masalah yang nantinya digunakan oleh penulis sebagai pedoman untuk menghindari terjadinya penyimpangan dari pokok permasalahan. Berikut batasan masalah dalam penelitian ini:

1. Aplikasi yang dibangun berbasis android, digunakan untuk media penjualan online produk tapis pada toko Ninda Tapis Lampung.

2. Peneliti menggunakan algoritma string matching brute force untuk pencarian nama produk tapis pada toko Ninda Tapis Lampung.

3. Objek penelitian yang digunakan adalah toko Ninda Tapis Lampung.

4. Aplikasi dapat menampilkan semua jenis produk beserta harga masing-masing produk. 
5. Aplikasi dapat menampilkan daftar produk terbaru.

6. Konsumen yang terdaftar sebagai member atau sudah melakukan registrasi user dapat melihat dan mengomentari produk.

7. Aplikasi bersifat online dan harus ada koneksi internet.

D. Tujuan Penelitian

Tujuan yang ingin dicapai dalam penelitian ini yaitu:

1. Untuk merancang dan membangun sebuah aplikasi penjualan online berbasis android yang memberikan kemudahan bagi konsumen/pelanggan dalam proses pemesanan tapis serta memberikan informasi tentang produk tapis yang dijual di toko Ninda Tapis Lampung.

2. Untuk menerapkan algoritma string matching brute force dalam proses pencarian nama produk tapis pada toko Ninda Tapis Lampung.

\section{E. Manfaat Penelitian}

Adapun manfaat dari penelitian ini yaitu:

1. Bagi Pelanggan/User:

Aplikasi penjualan online dengan menggunakan algoritma string matching brute force dapat memberikan informasi seputar produk tapis yang ada pada toko Ninda Tapis Lampung baik produk terbaru atau terlama serta memberikan kemudahan bagi konsumen untuk memesan produk tapis yang diinginkan hanya dengan menggunakan smartphone androidnya tanpa harus datang ke toko dan meninggalkan rumahnya. Konsumen dapat berbelanja atau mengolah berbagai transaksi lainnya dalam 24 jam sepanjang hari.

2. Bagi Toko Ninda Tapis Lampung/Admin
Dengan melakukan kegiatan bisnis secara online, toko Ninda Tapis Lampung akan dapat menjangkau pelanggan diseluruh wilayah Lampung bahkan luar Lampung, semakin banyak pelanggan semakin banyak pula keuntungan yang didapatkan. Sistem penjualan online berbasis android pada toko Ninda Tapis Lampung dapat memperluas pasar penjualan tapis, memperkenalkan toko Ninda Tapis Lampung dan meningkatkan jumlah transaksi penjualan.

\section{LANDASAN TEORI}

\section{A. Android}

Android adalah software untuk perangkat mobile yang mencakup sistem operasi, middleware, dan kunci aplikasi. Android SDK (Software Development Kit) menyediakan tools dan API yang diperlukan untuk memulai mengembangkan aplikasi dengan menggunakan bahasa Java (Holla, S. \& Katti, M. 2012). [5] Android merupakan sebuah sistem operasi untuk smartphone dan Tablet. Sistem operasi dapat diilustrasikan sebagai 'jembatan' antara piranti (device) dan penggunanya, sehingga pengguna bisa berinteraksi dengan device-nya dan menjalankan aplikasi-aplikasi yang tersedia pada device. [16]

\section{B. Pencocokan String}

Pengertian string menurut Dictionary of Algorithms and Data Structures, National Institute of Standards and Technology(NIST) adalah susunan dari karakter-karakter (angka, alfabet atau karakter yang lain) dan biasanya direpresentasikan sebagai struktur dan array. String dapat berupa kata, frase, atau kalimat. Pencocokan string (string matching) merupakan bagian penting dari sebuah proses pencarian string (string searching) dalam 
sebuah dokumen. Hasil dari sebuah pencarian string dokumen tergantung dari teknik dan cara pencocokan string yang digunakan. [3]

\section{Algoritma Brute Force}

Salah satu Algoritma String Matching adalah algoritma Brute Force. Cara kerja algoritma ini adalah dengan membandingkan satupersatu antara karakter di teks dan di pola dari kiri ke kanan. Misalnya i menyatakan indeks pada teks (antara 0 sampai $\mathrm{n}-1$ ) dan $\mathrm{j}$ menyatakan indeks dari pola (antara 0 sampai $\mathrm{m}-1)$. Window diletakkan di posisi palingkiri dari teks, lalu lakukan perbandingan pertama, yaitu antara $\mathrm{T}[0]$ dan $\mathrm{P}[0]$. Jika terjadi kecocokan maka masing-masing indeks akan dinaikkan satu, jadi jika misalnya $\mathrm{T}[0]=$ $\mathrm{P}[0]$, maka $\mathrm{i}$ dan $\mathrm{j}$ dinaikkan satu sehingga selanjutnya adalah membandingkan T[1] dan $\mathrm{P}[1]$. Jika terjadi ketidakcocokan maka indeks $\mathrm{j}$ akan dikembalikan ke awal pola yaitu $\mathrm{j}=0$ dan window akan digeser satu ke kanan sehingga indeks i sama dengan satu, i $=1$. Sehingga perbandingan selanjutnya adalah antara $\mathrm{T}[1]$ dan $\mathrm{P}[0]$. Hal ini adalah ciri algoritma brute force, yaitu jika terjadi ketidakcocokan maka window-nya pasti akan digeser ke kanan sebanyak satu. Perbandingan ini akan dilakukan sampai batas kanan dari window melebihi dari batas kanan teks. Jika sampai pada akhir dari pola $(\mathrm{j}=\mathrm{m}-1)$ maka artinya terdapat pola yang dicari pada teks, yang dimulai dari $\mathrm{T}[\mathrm{I}-\mathrm{m}]$. sedangkan jika akhir dari teks dicapai sebelum akhir dari pola dicapai maka pola yang dicari tidak ada pada teks (Darmawan Utomo \& Eric Wijaya Harjo, 2008). [14]

\section{PHP}

PHP merupakan singkatan dari "Hypertext Preprocessor", adalah sebuah bahasa scripting yang terpasang pada HTML (Hypertext Markup Language). Sebagian besar sintaks mirip dengan bahasa C, Java, asp dan Perl, ditambah beberapa fungsi PHP (Hypertext Preprocessor) yang spesifik. Tujuan utama bahasa ini adalah untuk memungkinkan perancang web untuk menulis halaman web dinamik dengan cepat. [7]

\section{E. Web Server}

Web server memiliki fungsi untuk memanipulasi data pada database dan menghasilkan dokumen yang memiliki format XML sebagai penghubung client android dan database sebagai media untuk menyimpan informasi. Dokumen kode program yang membentuk web server merupakan gabungan dari bahasa pemrograman HTML, PHP dan MySQL. [8]

\section{F. Xampp}

Xampp merupakan salah satu software web server yang dapat digunakan untuk mengatasi masalah PHP dan MySQL jika dirasa sulit. PHP, MySQL, Apache tergabung dalam satu software yaitu XAMPP. Penginstalan XAMPP tidak perlu melakukan perubahan pada register Windows dan tidak perlu meng-edit file konfigurasinya. Menginstall XAMPP tidak perlu meng-install PHP, MySQL, ataupun Apache.

\section{G. UML (Unified Modeling Language)}

Menurut Rossa dan Shalahuddin, UML (Unified Modeling Language) adalah salah satu standar bahasa yang banyak digunakan di dunia industri untuk mendefinisikan requirement, membuat analisis dan desain, serta menggambarkanarsitektur dalam pemrograman berorientasi objek. UML tidak hanya digunakan dalam pemodelan perangkat lunak, namun hampir dalam semua bidang yang membutuhkan pemodelan. [13]

\section{METODE PENELITIAN}
A. Metode Pengumpulan Data 
Dalam metode prototype, langkah pertama yang dilakukan adalah pengumpulan data. Metode pengumpulan data adalah cara atau teknik yang dilakukan dalam memperoleh data pendukung penelitian. Teknik yang digunakan adalah sebagai berikut :

1. Pengamatan (Observasi)

Dilakukan pengamatan secara langsung dengan karyawan Toko Ninda Tapis Lampung untuk mendapatkan keterangan-keterangan mengenai kegiatan jual beli produk tapis dan melihat secara langsung jenis-jenis produk tapis yang dijual di Toko Ninda Tapis Lampung.

2. Wawancara

Wawancara dilakukan secara langsung dengan karyawan Toko Ninda Tapis Lampung untuk mendapatkan keterangan-keterangan mengenai sejarah berdirinya toko, pemilik, jenis-jenis produk tapis yang dijual, serta sistem penjualan produk tapis yang digunakan.

3. Studi Pustaka

Pengumpulan data dengan cara mengumpulkan, mempelajari, dan menganalisis bahan-bahan berupa buku, jurnal ilmiah yang mendukung serta berhubungan dengan penelitian ini.

\section{B. Analisis Kebutuhan Pengguna}

Pada tahap ini, peneliti bekerja sama dengan pengguna dari sistem yang akan diusulkan untuk memperoleh informasi dasar yang dibutuhkan oleh pengguna terhadap sistem. Pengguna dari sistem ini dibagi menjadi 2 :

1. Admin (Karyawan Toko)

Orang yang di izinkan untuk mengawasi dan mengontrol akses informasi dan data yang ada pada aplikasi Penjualan Tapis berbasis Android tersebut.

2. Pengguna (Konsumen/pelanggan)

User atau pengguna untuk aplikasi ini adalah semua kalangan. Pengguna disini tidak dituntut untuk mengerti bagaimana program berjalan tetapi pengguna dituntut hanya mengerti menggunakan aplikasi ini setelah terinstal pada smartphone Android pengguna..

Berdasarkan analisa kebutuhan pengguna, maka diperoleh beberapa informasi sebagai berikut:

1. Perlunya sebuah aplikasi sebagai media pemesanan produk tapis secara online sehingga mempermudah konsumen/pelanggan untuk memesan produk tapis tanpa harus datang ke toko.

2. Perlu adanya sistem pembayaran online sehingga mempermudah konsumen untuk membayar produk tapis yang dibeli.

3. Perlu adanya media penyampaian informasi produk tapis dari pihak toko kepada konsumen secara online.

4. Media aplikasi yang dibangun dapat digunakan dengan mudah oleh konsumen/pelanggan melalui pemanfaatan teknologi berbasis android.

\section{Analisis Algoritma yang Digunakan}

Pada analisis algoritma yang digunakan adalah untuk metode pencarian nama produk tapis mengadopsi metode algoritma string matching yaitu algoritma brute force. Sistem pencarian dilakukan dari kiri kekanan untuk menentukan kata yang dicari.

\section{Algoritma Brute Force}

Algoritma Brute force melakukan pencocokan satu persatu (dari kiri ke kanan) karakter di pattern dengan karakter di text. Misalkan T menyatakan text, $\mathrm{P}$ menyatakan pattern, $\mathrm{n}$ menyatakan panjang text, $\mathrm{m}$ menyatakan panjang pattern, $\mathrm{x}$ menyatakan indeks text (0 sampai $\mathrm{n}-1)$, y menyatakan indeks pattern (0 sampai m-1), kotak pencarian diasumsikan sebagai kotak di dalam text sepanjang dengan panjang pattern untuk mewakili langkah-langkah 
pencocokan string. Selanjutnya, mula-mula posisi kotak pencarian diletakan di posisi paling kiri. Lalu dilakukan perbandingan pertama antara $\mathrm{T}[0]$ dan $\mathrm{P}[0]$, jika terjadi kecocokan maka indeks text dan pattern ditambah 1. Kemudian dilakukan perbandingan selanjutnya sampai batas kanan kotak pencarian sama dengan batas kanan text. Jika y sama dengan m-1 maka pattern ditemukan dalam text.

\begin{tabular}{|l|l|l|l|l|l|l|l|}
\hline M & A & T & A & K & I & B & \\
\hline
\end{tabular}

\begin{tabular}{|c|c|c|c|c|c|c|c|c|}
\hline 1 & $\mathrm{~K}$ & $\mathrm{I}$ & $\mathrm{B}$ & $\mathrm{A}$ & $\mathrm{U}$ & & & \\
\hline 2 & & $\mathrm{~K}$ & $\mathrm{I}$ & $\mathrm{B}$ & $\mathrm{A}$ & $\mathrm{U}$ & & \\
\hline 3 & & & $\mathrm{~K}$ & $\mathrm{I}$ & $\mathrm{B}$ & $\mathrm{A}$ & $\mathrm{U}$ & \\
\hline 4 & & & & $\mathrm{~K}$ & $\mathrm{I}$ & $\mathrm{B}$ & $\mathrm{A}$ & \\
\hline 5 & & & & & $\mathrm{~K}$ & $\mathrm{I}$ & $\mathrm{B}$ & \\
\hline
\end{tabular}

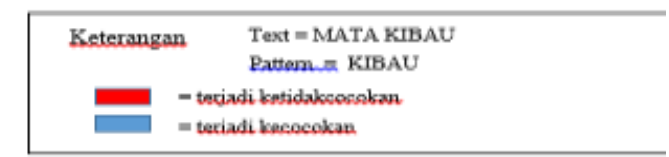

Gambar 3.1.7.1 Pencarian menggunakan algoritma

\section{HASIL DAN PEMBAHASAN}

4.1 Hasil

Melalui tahap perancangan dan pengumpulan kebutuhan serta melewati tahap implementasi hasil perancangan, maka dihasilkan aplikasi yang diberi nama aplikasi NTL (Ninda Tapis Lampung) sebagai media jual beli produk tapis secara online. Aplikasi NTL (Ninda Tapis Lampung) menerapkan algoritma Brute Force pada search box untuk mencari nama produk tapis yang dijual di toko Ninda Tapis Lampung.

\subsubsection{Tampilan Halaman Utama User}

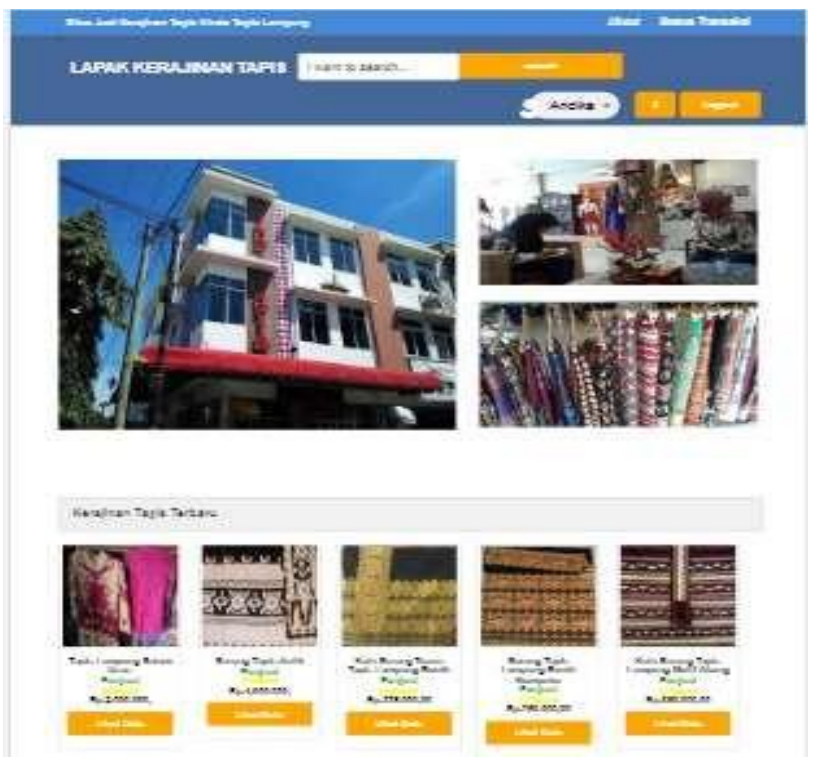

4.1.2 Tampilan Halaman Utama Admin
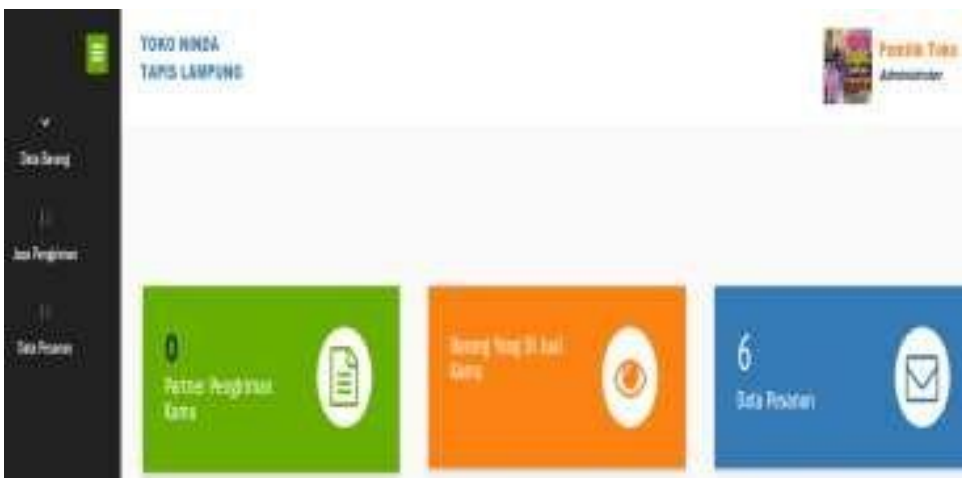

\subsection{Pembahasan}

4.2.1 Pembahasan Algoritma Brute Force

Algoritma brute force adalah algoritma untuk mencocokkan pattern dengan semua teks antara 0 dan n-m untuk menemukan keberadaan pattern dalam teks (Sarno et al. 2012). Di dalam pencocokkan string, terdapat istilah teks dan pattern. Teks merupakan kata yang dicari dan dicocokkan dengan pattern. Sedangkan pattern merupakan kata yang diinputkan untuk dicocokkan. Langkahlangkah yang dilakukan algoritma ini saat mencocokkan string adalah: 
1. Algoritma brute force mulai mencocokkan pattern dari awal teks.

2. Dari kiri ke kanan, algoritma ini akan mencocokkan karakter per karakter pattern dengan karakter pada teks yang bersesuaian, sampai salah satu kondisi berikut terpenuhi :

a. Karakter di pattern dan di teks yang dibandingkan tidak cocok.

b. Semua karakter di pattern cocok. Kemudian algoritma akan memberitahukan penemuan di posisi ini.

c. Algoritma kemudian terus menggeser pattern sebesar satu ke kanan, dan mengulangi langkah ke-2 sampai pattern berada di ujung teks.

\subsection{Pengujian Algoritma Brute Force pada}

\section{Aplikasi NTL}

User mengetikan nama tapis yang ingin dicari pada search box. Selanjutnya sistem akan melakukan pencarian dan pencocokan kata dengan nama tapis yang terdapat pada database. Kemudian sistem akan menampilkan hasil pencarian nama tapis yang dicari serta lama waktu pencarian (running time).

\section{Contoh 1 :}

User memasukkan kata tentang nama tapis yang akan dicari seperti contoh: "sarung tapis antik" maka sistem akan menampilkan hasil pencarian produk sarung tapis antic beserta lama waktu pencariannya (running time). Hasil pengujian dapat dilihat pada gambar 4.3.1.
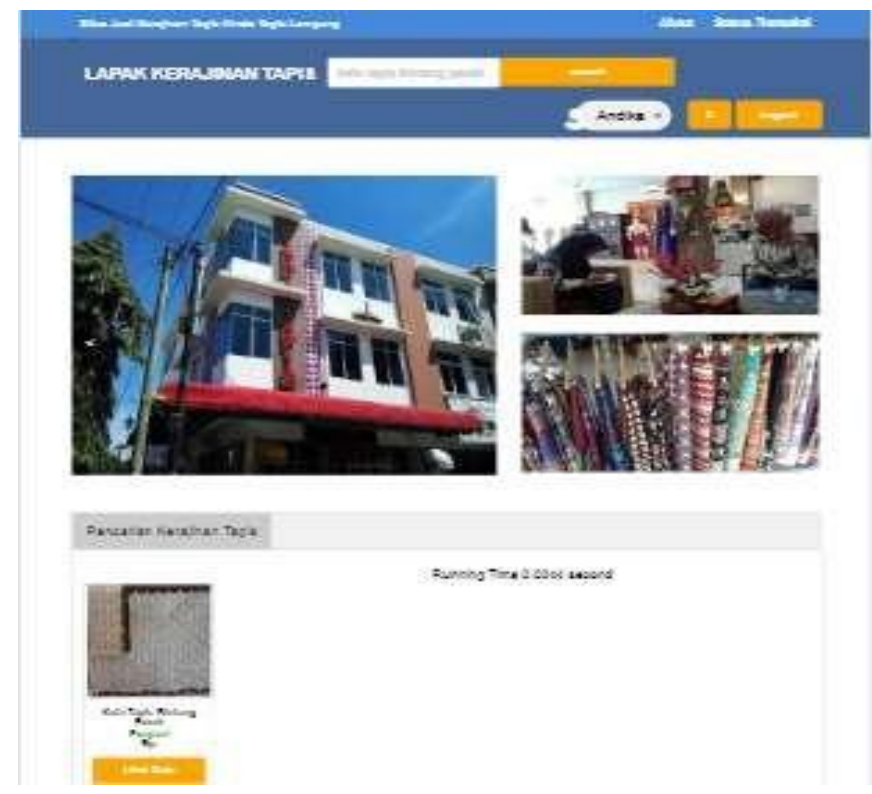

\section{SIMPULAN DAN SARAN}

\subsection{Simpulan}

Perancangan dan implementasi aplikasi penjualan tapis Lampung berbasis android menggunakan algoritma string matching yang telah dilakukan dapat disimpulkan sebagai berikut:

1. Aplikasi penjualan tapis pada toko Ninda Tapis Lampung dapat mempermudah konsumen/pelanggan untuk melakukan transaksi jual beli secara online yang dapat diakses kapan saja dan dimana saja dengan menggunakan smartphone yang mereka miliki.

2. Media penjualan tapis online ini menampilkan informasi tentang nama produk tapis, deskripsi produk, kategori produk, harga produk beserta diskon masing-masing produk tapis. Sehingga dapat mempermudah konsumen/pelanggan untuk memilih produk yang akan dipesan dan mengurangi kesalahan komunikasi antar penjual dan pembeli. 
3. Aplikasi Ninda Tapis Lampung menerapkan Algoritma String Matching Brute Force pada search box untuk mencari nama produk tapis yang diinginkan.

\subsection{Saran}

Berdasarkan kesimpulan yang ada maka penulis memiliki beberapa saran yang mungkin dapat dijadikan sebagai bahan acuan, masukan atau perbandingan sebagai berikut :

1. Bagi penelitian selanjutnya diharapkan dapat membuat aplikasi ini menjadi lebih menarik dengan kombinasi warna dan desain yang cocok untuk aplikasi ini.

2. Aplikasi penjualan tapis ini dapat dikembangkan dengan menerapkan sistem notifikasi online pada admin.

3. Aplikasi penjualan tapis Lampung berbasis Android ini dapat dikembangkan agar dapat dijalankan di sistem operasi lainnya seperti iOS, Apple, Blackberry, dan Windows Mobile.

\section{DAFTAR PUSTAKA}

[1] Antonius Rahmat C. 2010. Algoritma dan Pemrograman dengan Bahasa C. Penerbit Andi, Yogyakarta.

[2] Badins. 2018. "Pengertian Kain Tapis Lampung". Dalam http://tapisindahlampung.blogspot.co. id/2018/01/pengertian-kaintapislampung.html, diakses tanggal 5 April 2018.

[3] Bulolo, E. 2013. Implementasi Algoritma String Matching Dalam Pencarian Surat Dan Ayat Dalam Bible Berbasis Android. Pelita Informatika Budi Darma, 3, ISSN: 2301-9425.

[4] H. Nazruddin Safaat. 2012. Pemrograman Aplikasi Mobile
Smartphone dan Tablet PC Berbasis Android. Bandung.

[5] Holla, S. \& Katti, M. 2012. Android Based Mobile Application Development and its Security. International Journal of Computer Trends and Technology. Vol. 3, No. 1, pp. 486-490.

[6] M.Rudianto, Arief. 2011.

Pemrograman Web Dinamis

Menggunakan Php dan Mysql. Yogyakarta: C.V ANDI OFFSET.

[7] Nore, Viktor Nicolas. 2013. Perancangan Sistem Informasi Penjualan Dan Pemesanan Produk Berbasis Web. Skripsi, pada Jurusan Sistem Informasi, Fakultas Teknik Universitas Widyatama, Bandung.

[8] Petrus Santoso, Poundra Kartika P. 2013. Aplikasi Toko Tas Online Berbasis Android. Jurnal Dimensi Teknik Elektro. Vol. 1, No. 1, pp. 1217.

[9] Pressman, R.S. 2012. Rekayasa Perangkat Lunak, Edisi ke- 7, Buku I, Penerbit Andi, Yogyakarta.

[10] Pressman, R.S. 2010. Software Engineering. Penerbit Mc Graw Hill, New York.

[11] Satyaputra. 2014. Beginning Android Programming With ADTBundle. (P.E.M. Komputindo,Ed). Jakarta.

[12] Sholih, F. B. 2014. Perancangan Aplikasi Penjualan Batik Berbasis Android. Skripsi, pada Jurusan Teknik Informatika, Fakultas Komunikasi dan Informatika Universitas Muhammadiyah Surakarta, Surakarta.

[13] Rossa.A.S \& M. Shalahuddin. 2013. Perekayasa Perangkat Lunak Terstruktur dan Berorientasi Objek. Bandung: Informatika.

[14] U. Darmawan, H. Eric Wijaya, Handoko. 2008. Perbandingan Algoritma String Searching Brute Force, Knutt Morris Pratt, Boyer 
Moore, Dan Karp Rabin Pada Teks Alkitab Bahasa Indonesia. Techne Jurnal Ilmiah Elektronika. Vol. 7, No. 1, pp. 1-13.

[15] W. Hendi, S. Shinta Wellia. 2015. Rancang Bangun Mobile Commerce Berbasis Android Pada Toko Duta Buku Semarang. Techno.COM, Vol. 14, No. 2, pp. 98-107.

[16] Yuni Puspita Sari, Membangun Kamus Obstetri Berbasis Android (Studi Kasus: Kampus Kebidanan Adila Bandar Lampung). Jurnal Informatika. Vol. 16, No. 1, Juni 2016. 